\title{
Mutton mortadella supplemented with yacón meal
}

\author{
Alexandre Cristiano Santos Júnior ${ }^{*} \odot$ Fábio da Costa Henry ${ }^{1} \odot$ Jonhny de Azevedo Maia Júnior ${ }^{1}$ \\ Monique Moreira Moulin ${ }^{2}$ (- Suzana Maria Della Lucia ${ }^{3}$ Célia Raquel Quirino ${ }^{1}$ \\ Antonio Manoel Maradini Filho ${ }^{3}$ Beatriz Módulo Busato ${ }^{3}$
}

${ }^{1}$ Centro de Ciências e Tecnologias Agropecuárias (CCTA), Universidade Estadual do Norte Fluminense Darcy Ribeiro (UENF), Campos dos Goytacazes, 28013-602, RJ, Brasil. E-mail: junincsj@yahoo.com.br. "Corresponding author.

${ }^{2}$ Instituto Federal do Espírito Santo (IFES), Alegre, ES, Brasil.

${ }^{3}$ Departamento de Engenharia de Alimentos, Universidade Federal do Espírito Santo (UFES), Alegre, ES, Brasil.

ABSTRACT: This study evaluated the effect of different yacón meal concentrations (Smallanthus sonchifolia) on the physicochemical, microbiological, and sensory characteristics of four mortadella formulations (F1, F2, F3, and control) prepared with mutton, pork fat, and additives. All formulations met the physicochemical and microbiological standards defined in regulations for mortadella production in Brazil. Control and F1 were the formulations with better acceptance scores, compared with F2 and F3. The judges stated favorable purchase intention for the control, F1 and F2 formulations. Results showed that mutton mortadella supplemented with yacón meal is a promising alternative in the manufacture of healthier meat products.

Key words: mutton, mortadella, Smallanthus sonchifolia.

Mortadela de carne ovina suplementada com farinha de batata yacon

RESUMO: Este estudo avaliou o efeito de diferentes concentrações de farinha de yacon (Smallanthus sonchifolia) sobre as características físico-químicas, microbiológicas e sensoriais de quatro formulações de mortadelas (F1, F2, F3 e controle) preparadas com carne de ovinos, gordura suína e aditivos. Todas as formulações atenderam aos padrões fisico-químicos e microbiológicos definidos nas regulamentações para produção de mortadela no Brasil. As formulações controle e F1 obtiveram as melhores pontuações de aceitação, em comparação com F2 e F3. Os julgadores declararam intenção de compra favorável para as formulações controle, F1 e F2. Os resultados mostram que a mortadela de carne ovina suplementada com farinha de yacon é uma alternativa promissora na fabricação de produtos cárneos mais saudáveis.

Palavras-chave: ovinos, mortadela, Smallanthus sonchifolia.

\section{INTRODUCTION}

Several studies have examined the development of new, healthier foods based on the protective effect of substances in foods on human health (DOMÉNECH-ASENSI et al., 2013; MÉNDEZ-ZAMORA et al., 2015). Much research has also looked into the effect of adding nutritional supplements like vitamins, minerals, and bioactive compounds with confirmed physiological functions such as dietary fiber, natural pigments, antioxidant agents, and other additives to foods (CARDOSO et al., 2013; MAIA JÚNIOR et al., 2013). In this scenario, the food industry faces increasing challenges in the effort to develop and commercialize healthier foods that meet customer requirements more effectively.

Meat products take an important position in the development of healthier foods, and numerous studies have been carried out to produce innovative formulations that achieve functional status if they perform a specific role in health, in addition to their expected nutritional potential (DUTRA et al., 2013; MÉNDEZ-ZAMORA et al., 2015; LEITE et al., 2015).

Formulated mostly with pork, mortadella is one of the meat products most consumed by the Brazilian population. But mutton is now considered a viable alternative to pork in the production of several skin-encased products due to its high nutritional and sensory attributes. For example, mutton contains considerable levels of protein and iron besides attractively low levels of lipids, compared with other types of meat. For these reasons, a considerable body of research has placed mutton as a feasible alternative raw material in the production of healthier skin-encased products 
(LIMA JÚNIOR et al., 2013; GUERRA et al., 2012; BURIN et al., 2015).

Flours produced from various plant species may also be an attractive alternative as functional ingredients in meat-encased products (CARDOSO et al., 2013). The flour produced from yacón (Smallanthus sonchifolia) is an interesting candidate in this purpose, since it contains bioactive compounds like fructooligosaccharides (FOS), inulin, and phenolic compounds (DELGADO et al., 2013). The human organism does not produce any enzyme that hydrolyzes FOS, so these compounds cross the digestive tract unmetabolized, providing low energy levels. Therefore, they become an interesting ingredient in diets which aim to treat obesity and control the chronic conditions associated with the disease (BORGES et al., 2012).

In other words, the development of new meat products containing alternative ingredients as well as functional compounds becomes fertile ground for research and development of commercially feasible foods. In this context, this study evaluated the physicochemical, microbiological, and sensory characteristics of mortadella formulations prepared with mutton and different concentrations of yacón meal.

\section{MATERIALS AND METHODS}

\section{Study location}

All experimental procedures were carried out in the laboratories of Meat Processing, Applied Chemistry, and Microbiology of the Instituto Federal Espírito Santo (IFES, Campus de Alegre, ES) and the laboratory of Sensory Analysis of the Center for Agriculture Studies of the Universidade Federal do Espírito Santo (CCA-UFES, Campus de Alegre, ES).

\section{Raw materials}

The mortadella formulations analyzed were prepared with mutton shoulder steak from Dorper and Santa Inês sheep bred in confinement in Santa Barbara farm in the municipality of Muniz Freire, state of Espírito Santo (ES), Brazil. All animals were slaughtered in an abattoir (Cofril) located in the municipality of Atílio Vivácqua, ES. Meat cuts were inspected and certified for human consumption by the Food Product Survey Service of ES (SIE/IDAF).

The raw material was stored in walk-in freezers at $-18^{\circ} \mathrm{C}$ upon preparation of formulations. Yacón meal and the other additives were purchased in stores specialized in natural plant products and processed additives used in the manufacture of skinencased products.

\section{Preparation of mortadella formulations}

Four mortadella formulations were prepared replacing pork fat for different amounts of yacón meal (Control, F1, F2, and F3) according to GUERRA et al. (2012), with modifications. The preparation followed the food identity standards defined in Brazilian regulations (BRASIL, 2000). Percent contents of raw material and additives used in each formulation are shown in table 1.

Mortadella formulations were prepared according to GUERRA et al. (2012), with modifications. The frozen mutton shoulder cuts were

Table 1 - Percentage amounts of raw material and additives used in four mortadella formulations prepared with yacón meal.

\begin{tabular}{lcccc}
\hline Raw material & Control & F1 & F2 & F3 \\
Meat & 67.00 & 67.00 & 67.00 & 67.00 \\
Fat & 30.00 & 27.00 & 24.00 & 21.00 \\
Yacón meal $^{1}$ & 0.00 & 1.25 & 2.50 & 5.00 \\
Sugar $^{2}$ & 0.10 & 0.10 & 0.10 & 0.10 \\
${\text { Salt }(\mathrm{NaCl})^{3}}^{\text {Sodium nitrite }}$ & 2.10 & 2.10 & 2.10 & 2.10 \\
Emulsifier $^{5}$ & 0.20 & 0.20 & 0.20 & 0.20 \\
Color fixer $^{6}$ & 0.30 & 0.30 & 0.30 & 0.30 \\
Water & 0.30 & 0.30 & 0.30 & 0.30 \\
\hline
\end{tabular}

${ }^{1}$ Natural Life ${ }^{\circledR}$ yacón meal

${ }^{2}$ União ${ }^{\circledR}$ sugar

${ }^{3} \mathrm{Cisne}^{\circledR}$ salt

${ }^{4}$ Kura K007 - Doremus ${ }^{\circledR}$ curing salt

${ }^{5} \mathrm{Ibrac}^{\mathbb{B}}$ emulsifier

${ }^{6} \mathrm{Ibrac}^{\mathbb{B}}$ color fixer 
thawed at approximately $4^{\circ} \mathrm{C}$. Next, mutton and fat were serially ground using a meat grinder equipped with grind plates with $8-\mathrm{mm}, 5-\mathrm{mm}$, and 3-mm outlets. All meat samples were ground three times through each grind plate. Then, mutton, fat, yacón meal, and the other additives were weighed for each formulation and blended in a food processor for approximately $6 \mathrm{~min}$ until the material was thoroughly mixed. Mortadella formulations were encased in an appropriate polyethylene bag to cook mortadella purchased in a specialized shop regularly inspected by local health authorities.

Formulations were cooked in a stainless steel mold in a double bath at roughly $80^{\circ} \mathrm{C}$ until the temperature in the center of mass reached $74^{\circ} \mathrm{C}$. After, products were properly labeled, vacuum-packaged in polyethylene bags, and kept at $4{ }^{\circ} \mathrm{C}$ upon analyses and evaluation of shelf life.

\section{Physicochemical analysis}

Samples of each mortadella formulation were ground and homogenized. Humidity of samples was analyzed in a stove at $105^{\circ} \mathrm{C}$, while ash content was determined by incineration in muffle furnace at $550^{\circ} \mathrm{C}$. Protein content was assessed using the conventional Kjeldhal method, fat content was determined by direct Shoxhlet extraction, dietary fiber content was established by a gravimetric method after acid digestion, and non-nitrogen content were established by subtraction from the other variables. All physicochemical analyses were carried out according to AOAC (2000).

\section{Instrumental analyses}

Water activity (Aw) was estimated by direct reading at approximately $25^{\circ} \mathrm{C}$ in an Aw meter (Aqualab TE, Ecagon Devices, Pullman, WA). Also, $\mathrm{pH}$ was measured in a potentiometer using $10 \mathrm{~g}$ of each mortadella formulation homogenized in $100 \mathrm{ml}$ distilled water for $5 \mathrm{~min}$ (Schott Handylab).

Color was analyzed as described by RAMOS and GOMIDE (2007) using a colorimeter (MiniScan, EX HunterLab) and D65 as illuminant at an observation angle of $10^{\circ}$ according to the CIELAB color space. Results were shown as angular coordinates, in which the $\mathrm{L}^{*}$ axis reflects the lightness of a color $\left(L^{*}=0\right.$ represents absolute black, $L^{*}=100$ represents absolute white), the $\mathrm{a}^{*}$ axis represents the green shades $\left(-80<\mathrm{a}^{*}<0\right.$ represents green, $0<\mathrm{a}^{*}<100$ represents red), and the $b^{*}$ axis is for the color yellow $\left(-100<b^{*}<0\right.$ represents blue, $0<b^{*}<+70$ represents yellow). Saturation index was calculated using the equation $C^{*}=\left(a^{*} 2+b^{*} 2\right) 1 / 2$

\section{Microbiological analyses}

The microbiological analyses thermotolerant coliforms at $45^{\circ} \mathrm{C}$, coagulase-positive Staphylococcus, Salmonella sp., and sulphitereducing clostridia at $46^{\circ} \mathrm{C}$ of samples were done $10,45,90$, and 120 days after processing, carried out according to the official methods adopted by the Brazilian food inspection authority and carried out as proposed by SILVA et al. (2007).

\section{Sensory analysis}

Sensory analysis was conducted following the protocol proposed by MEILGAARD (2006). Sixty non-trained observers including students, staff members, and professors of CCA-UFES agreed to taste samples of formulations in a single session, declaring sensory impressions and purchase intention.

\section{Statistical analyses}

Results of the physicochemical analyses were compared using a complete randomized design with four treatments and three repeats for each mortadella formulation (control, F1, F2, and F3). Results were submitted to an analysis of variance (ANOVA), and means of treatments were compared using the Student-Newman-Keuls test and, for sensory analysis, the Tukey test at 5\% probability. The analyses were carried out in the Statistical Analysis System (SAS, version 9.2, 2013).

\section{RESULTS AND DISCUSSION}

\section{Physicochemical analyses}

Table 2 shows the results of the composition analysis (humidity, protein, fat, ash, dietary fiber, non-nitrogenated contents), yield, and instrumental analysis ( $\mathrm{pH}, \mathrm{Aw}$, color, and texture) of the mortadella formulations. Results showed that all mortadella formulations met the mean humidity contents established in Brazilian regulations for the product (65\%; BRASIL, 2000).

Minimum protein contents of all formulations were above the minimum acceptable value $(12 \%)$ established in the Brazilian regulation (BRASIL, 2000), but the values differed statistically between formulations $(\mathrm{P}>0.05)$. Used as stabilizer agent in emulsified food products, proteins affect the water-fat interface, reducing interfacial tension, improving the mixture of these ingredients, and preventing the coalescence of lipids. In other words, proteins are an essential ingredient in the preparation of emulsified skin-encased products with acceptable sensory characteristics (GUERRA et al., 2012). 
Table 2 - Means and standard deviations of physicochemical variables and yield of mortadella formulations prepared with different concentrations of yacón meal.

\begin{tabular}{|c|c|c|c|c|}
\hline \multirow[t]{2}{*}{ Variables } & \multirow[b]{2}{*}{ Control } & \multirow[b]{2}{*}{ F1 } & \multirow[b]{2}{*}{$\mathrm{F} 2$} & \\
\hline & & & & F3 \\
\hline Humidity (\%) & $56.40 \pm 0.10^{\mathrm{a}}$ & $55.00 \pm 0.10^{b}$ & $55.16 \pm 0.15^{b}$ & $54.60 \pm 0.15^{c}$ \\
\hline Proteins $(\%)$ & $16.00 \pm 0.00^{\mathrm{a}}$ & $18.23 \pm 0.06^{\mathrm{b}}$ & $18.43 \pm 0.40^{\mathrm{bc}}$ & $18.80 \pm 0.10^{\mathrm{c}}$ \\
\hline $\mathrm{Fat}^{\#}(\%)$ & $25.10 \pm 0.10^{\mathrm{a}}$ & $23.73 \pm 0.15^{b}$ & $22.03 \pm 0.38^{\mathrm{c}}$ & $20.13 \pm 0.15^{\mathrm{d}}$ \\
\hline Ash (\%) & $2.50 \pm 0.00^{\mathrm{a}}$ & $2.50 \pm 0.00^{\mathrm{a}}$ & $2.60 \pm 0.00^{\mathrm{a}}$ & $3.10 \pm 0.10^{\mathrm{b}}$ \\
\hline Dietary fiber (\%) & $0.00 \pm 0.00^{\mathrm{a}}$ & $0.30 \pm 0.00^{b}$ & $0.40 \pm 0.00^{\mathrm{c}}$ & $1.13 \pm 0.06^{\mathrm{d}}$ \\
\hline Non-nitrogenated extract. ${ }^{\# \#}(\%)$ & $0.00 \pm 0.00^{\mathrm{a}}$ & $0.24 \pm 0.06^{\mathrm{b}}$ & $1.38 \pm 0.06^{\mathrm{c}}$ & $2.24 \pm 0.06^{\mathrm{d}}$ \\
\hline Yield $(\%)$ & $67.83 \pm 1.05^{\mathrm{a}}$ & $68.30 \pm 1.20^{\mathrm{a}}$ & $72.06 \pm 3.05^{b}$ & $73.70 \pm 1.10^{b}$ \\
\hline $\mathrm{pH}$ & $5.97 \pm 0.09^{\mathrm{a}}$ & $5.87 \pm 0.08^{\mathrm{a}}$ & $5.87 \pm 0.06^{\mathrm{a}}$ & $5.86 \pm 0.02^{\mathrm{a}}$ \\
\hline Aw & $0.97 \pm 0.00^{\mathrm{a}}$ & $0.97 \pm 0.00^{\mathrm{a}}$ & $0.97 \pm 0.00^{\mathrm{a}}$ & $0.97 \pm 0.00^{\mathrm{a}}$ \\
\hline $\mathrm{L}^{*}$ & $59.84 \pm 0.34^{\mathrm{a}}$ & $56.02 \pm 0.60^{\mathrm{b}}$ & $54.34 \pm 0.29^{c}$ & $51.03 \pm 0.20^{\mathrm{d}}$ \\
\hline$a^{*}$ & $12.13 \pm 0.04^{\mathrm{a}}$ & $11.42 \pm 0.20^{b}$ & $10.59 \pm 0.03^{\mathrm{c}}$ & $9.97 \pm 0.11^{\mathrm{d}}$ \\
\hline$b^{*}$ & $12.47 \pm 0.37^{\mathrm{a}}$ & $13.35 \pm 0.18^{\mathrm{a}}$ & $14.27 \pm 0.31^{b}$ & $16.11 \pm 0.27^{\mathrm{c}}$ \\
\hline$c^{*}$ & $17.41 \pm 0.30^{\mathrm{a}}$ & $17.54 \pm 0.24^{\mathrm{a}}$ & $17.81 \pm 0.28^{b}$ & $18.94 \pm 0.29^{b}$ \\
\hline
\end{tabular}

Different letters in the same line indicate statistically significant differences $(\mathrm{P}<0.05)$ in the Student-Newman-Keuls test.

Fat levels varied significantly between formulations $(\mathrm{P}>0.05)$, as expected. However, it is important to emphasize that formulations met the maximum acceptable level of fat established in Brazilian regulations (30\%; BRASIL, 2000). According to GUERRA et al. (2012), lipid level is a very important parameter in mortadella, since fat improves texture and product flavor .

Results of the present study also showed that, in addition to improve the yield of F1, F2, and F3 compared with the control formulation (which did not include yacón meal), the increasing amounts of yacón meal in these formulations explain the statistically significant differences in the levels of ash, dietary fiber, and non-nitrogenated extract observed.

Overall, the percent composition of foods was similar to the values obtained for cooked skinencased mutton products formulated with yacón meal and flour from other plant species (DUTRA et al., 2013; BARRETTO et al., 2015; CONTADO et al., 2015; SANTOS JÚNIOR et al., 2017). Mean pH and Aw values of formulations did not differ statistically $(\mathrm{P}<0.05)$. Since $\mathrm{Aw}$ and $\mathrm{pH}$ are important determinants of microbial growth, it will be obvious that these parameters are significant for its resistance to spoilage. In the objective evaluation of color, $\mathrm{L}^{*}$ values, which represents luminosity $(0=$ black, $100=$ white $)$ varied significantly $(\mathrm{P}>0.05)$ between formulations. The higher the amount of yacón meal added, the darker the product obtained. With the lowest $\mathrm{L}^{*}$ value (51.03), F3 had presented the darkest color, while the control formulation was the lightest, with $\mathrm{L}^{*}$ of 59.84 .

Indicating the intensity of red color in food products $\left(-80<\mathrm{a}^{*}<0\right.$ represents green, $0<\mathrm{a}^{*}<100$ represents red), $a^{*}$ values varied statistically between formulations: the higher the amount of yacón meal added, the lighter the red tone of the product. Control formulation exhibited the most intense tone of red, with $\mathrm{a}^{*}$ of 12.13. In turn, F3 had the least intense red tone, with $\mathrm{a}^{*}$ of 9.97 .

Similarly, $\mathrm{b}^{*}$ values $\left(-100<\mathrm{b}^{*}<0\right.$ represents blue, $0<b^{*}<+70$ represents yellow) observed for the control formulation and F1 varied statistically compared with F2 and F3 $(\mathrm{P}>0.05)$. Expressing the intensity of yellow tones in mortadella, $b^{*}$ values indicated the intensity of brown tones in meat and meat products (BARRETO et al., 2015). Therefore, F2 and F3, which were prepared using high percent amounts of yacón meal, were more intensely brown. The influence of $\mathrm{a}^{*}$ and $\mathrm{b}^{*}$ values becomes more noticeable when the parameters are evaluated based on $\mathrm{C}^{*}$, whose values for the control formulation and F1 varied statistically, compared with F2 and F3 ( $\mathrm{P}>0.05)$.

The control formulation had the lightest color and the most intense red tone, while F1, F2, and F3 were increasingly darker, which may affect sensory acceptance. But the overall color results obtained were similar, agreeing with the findings published by Contado et al., (2015) in a study that examined hamlike meat products containing yacón meal. 


\section{Microbiological analyses}

Mean counts of thermotolerant coliforms, coagulase-positive Staphilococcus, Salmonella sp., and sulphite-reducing clostridia are shown in table 3 . Mortadella is a cooked meat product with a shelf-life of 60 days when stored at $4^{\circ} \mathrm{C}$. In the present study, all microbiological counts were below the maximum acceptable values defined by Brazilian regulations 120 days into storage. Such results are similar to what has been observed in other researches (GUERRA et al. 2012; CARDOSO et al. 2013). The excellent microbiological quality of the mortadella formulations analyzed is a direct consequence of the quality of raw materials used, besides the adoption of good manufacturing practices, use of additives that prevent the growth of deleterious microorganisms, and the vacuum-packaging system employed to store mortadellas.

\section{Sensory analysis}

Results of acceptance parameters and the purchase intention test for the mortadella formulations studied are shown in figure 1. The acceptance of the control formulation and F1 were similar for all sensory parameters considered $(\mathrm{P}<0.05)$. Except for flavor of F1 (6.7), the mean acceptance scores attributed to all other parameters were higher than 7.0. These formulations could be included in the categories "liked very much" and "liked moderately". For DUTCOSKY (2001), a product is considered to have good acceptance when one mean acceptance score is higher than 7.0 for any sensory parameter evaluated.

Mean acceptance scores considering color and overall impression of F2 were lower, compared with the control formulation and F1. Color, texture, and overall impression scores of these formulations varied significantly compared with F2 and F3. Acceptance score of F2 allows including it in the categories "liked moderately" and "liked slightly".

Acceptance score ofF3 was lower $(\mathrm{P}>0.05)$ in the parameters color, flavor, texture, and overall impression. Mean acceptance score was 6.0, which means that it can be included in the categories "liked slightly" and "indifferent". The poor acceptance of F3 is due to its darker color, milder intensity of the red tone, and lower level of fat (which plays an essential role in flavor and texture). So it may be inferred that the percent amount of yacón meal affects texture of mortadella and therefore the acceptance of F3, compared to the other formulations.

Mean scores in the purchase intention test did not differ statistically $(\mathrm{P}<0.05)$ for the control formulation, F1, and F2. Means varied between 3.8 and 3.5, which includes the formulations in the category "probably would buy". However, with a score of $3.1 \mathrm{~F} 3$ differed significantly from the other

Table 3 - Means and standard deviations of microorganism counts in mutton mortadella formulated with different amounts of yacón meal $10,45,90$, and 120 days after processing.

\begin{tabular}{|c|c|c|c|c|c|c|}
\hline \multirow{2}{*}{ Parameters } & \multirow{2}{*}{ Time } & \multicolumn{5}{|c|}{--Formulations----------------------------------- } \\
\hline & & Control & $\mathrm{F} 1$ & $\mathrm{~F} 2$ & F3 & Regulations $^{\mathrm{a}}$ \\
\hline \multirow{4}{*}{ Thermo-tolerant coliforms ${ }^{*}$} & 10 days & $<0.3$ & $<0.3$ & $<0.3$ & $<0.3$ & $<10^{3}$ \\
\hline & 45 days & $<0.3$ & $<0.3$ & $<0.3$ & $<0.3$ & $<10^{3}$ \\
\hline & 90 days & $<0.3$ & $<0.3$ & $<0.3$ & $<0.3$ & $<10^{3}$ \\
\hline & 120 days & $<0.3$ & $<0.3$ & $<0.3$ & $<0.3$ & $<10^{3}$ \\
\hline \multirow{4}{*}{ Coagulase-positive Staphylococcus ${ }^{* *}$} & 10 days & $<1.0$ & $<1.0$ & $<1.0$ & $<1.0$ & $3 \times 10^{3}$ \\
\hline & 45 days & $<1.0$ & $<1.0$ & $<1.0$ & $<1.0$ & $3 \times 10^{3}$ \\
\hline & 90 days & $<1.0$ & $<1.0$ & $<1.0$ & $<1.0$ & $3 \times 10^{3}$ \\
\hline & 120 days & $<1.0$ & $<1.0$ & $<1.0$ & $<1.0$ & $3 \times 10^{3}$ \\
\hline \multirow{4}{*}{ Sulphite-reducing Clostridium at $46^{\circ} \mathrm{C}^{* *}$} & 10 days & $<1.0$ & $<1.0$ & $<1.0$ & $<1.0$ & $5 \times 10^{2}$ \\
\hline & 45 days & $<1.0$ & $<1.0$ & $<1.0$ & $<1.0$ & $5 \times 10^{2}$ \\
\hline & 90 days & $<1.0$ & $<1.0$ & $<1.0$ & $<1.0$ & $5 \times 10^{2}$ \\
\hline & 120 days & $<1.0$ & $<1.0$ & $<1.0$ & $<1.0$ & $5 \times 10^{2}$ \\
\hline \multirow{4}{*}{ Salmonella sp. } & 10 days & absent & absent & absent & absent & absence \\
\hline & 45 days & absent & absent & absent & absent & absence \\
\hline & 90 days & absent & absent & absent & absent & absence \\
\hline & 120 days & absent & absent & absent & absent & absence \\
\hline
\end{tabular}

*Given as most probable number (MPN) per gram

${ }^{* *}$ Given as colony forming units (CFU) per gram

${ }^{\mathrm{a} B R A S I L . ~} 2001$. 


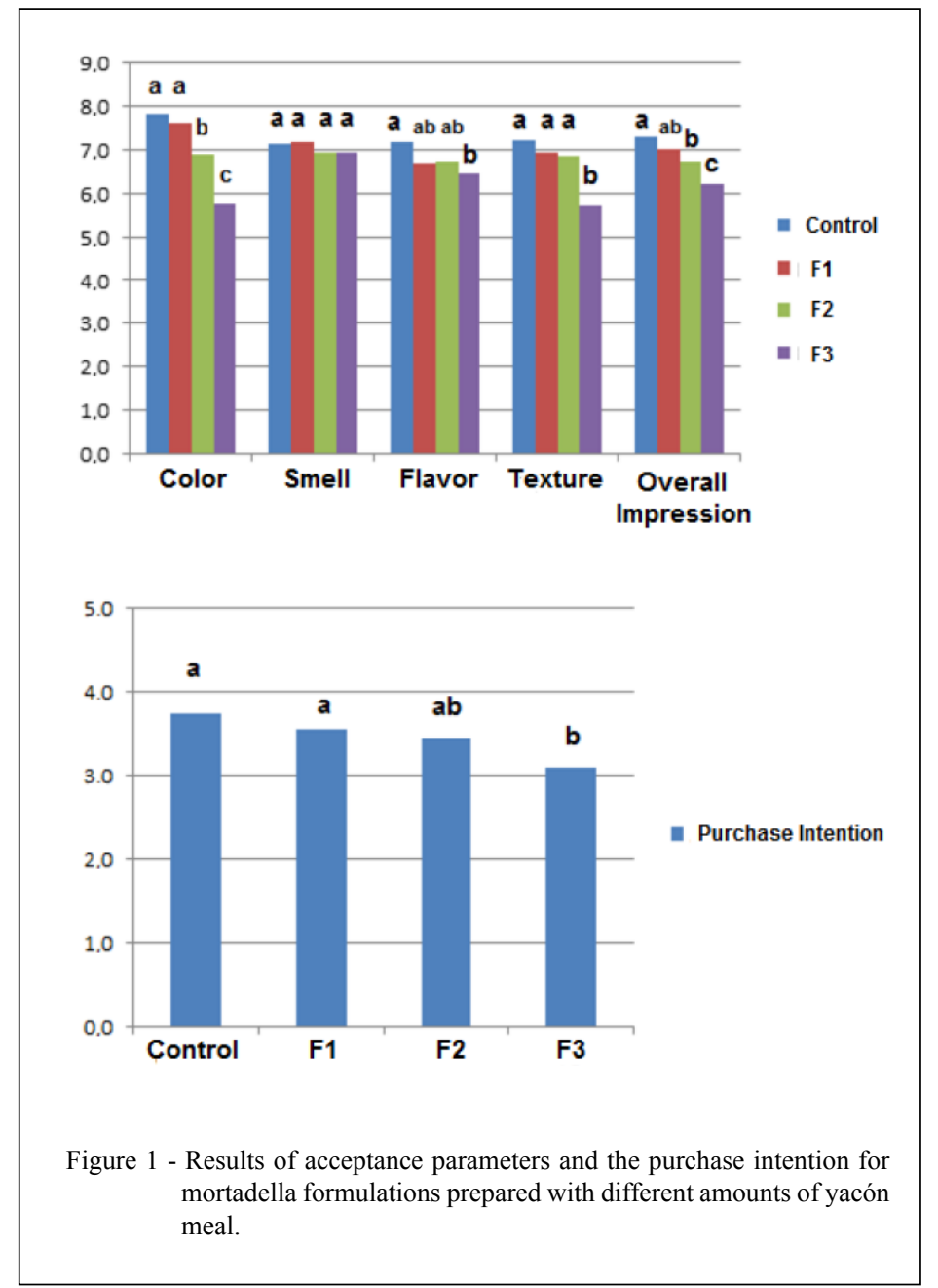

formulations ( $\mathrm{P}>0.05)$, and could be included in the category "maybe would buy/maybe would not buy". Also, F3 had the lowest purchase intention score, and the control formulation, F1, and F2 had good acceptance scores, when observers declared their favorable purchase intention.

\section{CONCLUSION}

The use of mutton and yacón meal is a promising alternative in the manufacture of healthierskinencased products. Physicochemical and microbiological parameters of varied between formulations, but all met the minimum percent values established in Brazilian regulations. As a rule, the control formulation and F1 had better acceptance compared to F2 and F3, though all were accepted, since observers manifested their favorable purchase intention. It should be stressed that partnerships between research centers and food industry are essential in the search for innovation toward the development of healthier products with potentially interesting performance on the commercial scale.

\section{ACKNOWLEDGMENTS}

The authors thank Instituto Federal do Espírito Santo (Ifes) andthe funding agencies Fundação Carlos Chagas Filho de Amparo à Pesquisa do Estado do Rio de Janeiro (FAPERJ) and Coordenação de Aperfeiçoamento de Pessoal de Nível Superior (CAPES).

\section{BIOETHICS AND COMMITTEE APPROVAL}

BIOSSECURITY

We authors of the article entitled "Mutton mortadella supplemented with yacón meal" declared, for all due purposes, the project that gave rise to the present data has 
not been submitted for evaluation to the Ethics Committee of the University /Research Institute "Universidade Estadual do Norte Fluminense Darcy Ribeiro", but we are aware of the contents of Resolution No. 466, of December 12, 2012 of the Brazilian National Health Council <http://conselho.saude.gov.br/ resolucoes/2012/Reso466.pdf $>$ if it involves human.

Thus, the authors assume full responsibility for the presented data and are available for possible questions, should they be required by the competent authorities.

\section{DECLARATION OF CONFLICTING OF INTERESTS}

The authors declare no conflict of interest. The founding sponsors had no role in the design of the study; in the collection, analyses, or interpretation of data; in the writing of the manuscript, and in the decision to publish the results.

\section{REFERENCES}

AOAC. Official methods of analysis of the AOAC. Viriginia: International Association of Official Analytical Chemists, 2000.

BARRETTO, A.C.S. et al. Effect of the addition of wheat fiber and partial pork back fat on the chemical composition, texture and sensory property of low-fat bologna sausage containing inulin and oat fiber. Food Science and Technology, v. 35, n. 1, p. 100-107, 2015. Available from: $<$ http://dx.doi.org/10.1590/1678-457X.6496>. Accessed: Nov. 12, 2017. doi: 10.1590/1678-457X.6496.

BORGES, J.T.S. et al. Yacon na alimentação humana: aspectos nutricionais, funcionais, utilização e toxicidade. Scientia Amazonica, v. 1, n. 3, p. 3-16, 2012. Available from: <http:// scientia-amazonia.org/wp-content/uploads/2016/06/v1-n3-3-162012.pdf>. Accessed: Nov. 21, 2017.

BRASIL. Instrução normativa n.4, de 31 de março de 2000. Regulamentos técnicos de identidade e qualidade de carne mecanicamente separada, de mortadela, de linguiça e de salsicha. Brasília: Diário Oficial da República Federativa do Brasil, 05 Abr. 2000, Seção 1, p. 6.

BURIN, P.C. et al Sensory analysis of the ham-like prepareds from beef andpantaneiros sheep of different categories. REDVET - Revista Electrónica de Veterinaria, v. 16, n. 2, p. 1-12, 2015. Available from: <http://www.veterinaria.org/revistas/redvet/ n020215/021510.pdf>. Accessed: Nov. 21, 2017.

CARDOSO, J.B.N. et al. Characterization of cooked ham containing pectin and potassium chloride. Journal of Food Processing and Preservation, v. 37, p. 100-108, 2013. Available from: $<$ https://doi. org/10.1111/j.1745-4549.2011.00625.x.>. Accessed: Dec. 12, 2017. doi: $10.1111 / \mathrm{j} .1745-4549.2011 .00625 . \mathrm{x}$

CONTADO, E.W.N.F. et al. Use of yacon flour and fructan extract in the formulation of luncheon meats. Brazilian Journal of Food Technology, v. 18, n. 1, p. 49-56, 2015. Available from: <http:// dx.doi.org/10.1590/1981-6723.3814>. Accessed: Dec. 11, 2017. doi: $10.1590 / 1981-6723.3814$.

DELGADO, G.T.C. et al. Yacon (Smallanthus sichifolius), functional food. Plant Foods for Human Nutrition, v. 68, p
222-228, 2013. Available from: <https://ink.springer.com/article/ 10.1007\%2Fs11130-013-0362-0>. Accessed: Dec. 15, 2017. doi: $10.1007 \% 2 \mathrm{Fs} 11130-013-0362-0$.

DOMÉNECH-ASENSI, G. et al. Effect of the addition of tomato paste on the nutritional and sensory properties of mortadella. Meat Science, v. 93, p. 213-219, 2013. Available from: $<$ https://doi. org/10.1016/j.meatsci.2012.08.021>. Accessed: Dec. 15, 2017. doi: 10.1016/j.meatsci.2012.08.021.

DUTCOSKY, S.D. Análise sensorial de alimentos, $3^{\mathrm{a}}$ ed Curitiba: Editora Universitária Champagnat, 2011.

DUTRA, M.P. et al.Technological and quality characteristics of cooked ham-type pâté elaborated with sheep meat. Small Ruminant Research. v. 115, p. 56-61, 2013. Available from: $<$ https://doi.org/10.1016/j.smallrumres.2013.08.007>. Accessed: Dec. 07, 2017. doi: 10.1016/j.smallrumres.2013.08.007.

GUERRA, I.C.D. et al. Spent lamb meat in the preparation of mortadella with different levels of pork fat. Ciência Rural, v. 42, n. 12 , p. 2288-2294, 2012. Available from: <http://dx.doi org/10.1590/S0103-84782012005000113>. Accessed: Dec. 17, 2017. doi: 10.1590/S0103-84782012005000113.

LEITE, A. et al. Physicochemical properties, fatty acid profile and sensory characteristics of sheep and goat meat sausages manufactured with different pork fat levels. Meat Science, v. 105, p. 114-120, 2015. Available from: <http://dx.doi.org/10.1016/j. meatsci.2015.03.015>. Accessed: Dec. 23, 2017. doi: 10.1016/j. meatsci.2015.03.015

LIMA JÚNIOR, D.M. et al. Oxidação lipídica e qualidade de carne ovina. Acta Veterinaria Brasilica, v. 7, n. 1, p. 14-28, 2013. Available from: <https://doi.org/10.21708/avb.2013.7.1.3119>. Accessed: Dec. 21, 2017. doi: 10.21708/avb.2013.7.1.3119.

MAIA JÚNIOR, J.A. et al. Reducing fat and sodium content in pork sausage. African Journal of Biotechnology, v. 12, p. 3847-3853, 2013. Available from: <http://dx.doi.org/10.5897/AJB2012.11919>. Accessed: Dec. 01, 2017. doi: 10.5897/AJB2012.11919.

MEILGAARD, M. et al. Sensory Evaluation Techniques. $4^{\mathrm{a}}$ ed. Boca Ratón: CRC Press, 2006.

MÉNDEZ-ZAMORA, G., et al. Fat reduction in the formulation of frankfurter sausages using inulin and pectin. Food Science and Technology, v. 35, n. 1, p. 25-31, 2015. Available from: <http:// dx.doi.org/10.1590/1678-457X.6417>. Accessed: Dec. 05, 2017. doi: 10.1590/1678-457X.6417.

RAMOS, E.M. and GOMIDE, L.A.M. Avaliação da qualidade de carnes: fundamentos e metodologias. Viçosa: UFV. 2007.

SANTOS JUNIOR, A.C.S. et al. Preparation and physico-chemica characterization of mutton mortadella supplemented with yacón meal. REDVET Revista Electrónica de Veterinaria, v. 18, n. 7, 1-10, 2017. Available from: < http://www.veterinaria.org/revistas/ redvet/n070717/071711.pdf>. Accessed: Dec. 05, 2017.

SAS. User's guide statistics. Cary: SAS Institute, 2003.

SILVA, N. et al. Manual de métodos de análise microbiológica de alimentos, 3 ed. São Paulo: Livraria Varela, 2007. 